\title{
The Effect of Service Quality, Customer Satisfaction and Corporate Image on Customer Loyalty in the banking sector in Indonesia
}

\author{
*Didit Darmawan ${ }^{1}$, Rahayu Mardikaningsih ${ }^{2}$, Surjo Hadi ${ }^{3}$ \\ ${ }^{1,2}$ Universitas of Mayjen Sungkono Mojokerto, Jawa Timur, Indonesia \\ ${ }^{3}$ Universitas of Kartini Surabaya, Jawa Timur, Indonesia \\ Corresponding Author:*dr.diditdarmawan@gmail.com
}

\begin{abstract}
The Main purpose of this study is to show the role of service quality, customer satisfaction and corporate image on customer loyalty. The research population is bank customers in East Java who have high involvement in decision making process. This study involved 250 respondents who came from retail customers from five largest banks in Indonesia. The research results indicate that service quality has significant positive effects on customer satisfaction, corporate image, and customer loyalty. Also, customer satisfaction has significant positive effects on corporate image. Finally, both of customer satisfaction and corporate image are found to have a significant positive effect on customer loyalty. The model indicates that corporate image has the bigger effect on customer loyalty when compared with both service quality and customer satisfaction. Service quality can enhance and create both of customer satisfaction and corporate image.he abstract should summarize the content of the paper.
\end{abstract}

Keywords: Service quality, customer satisfaction and corporate image, customer loyalty

\section{Introduction}

The growing banking industry in Indonesia has led to competition for as many customers to raise funds from the public as possible. According to the Financial Services Authority/ Otoritas Jasa Keuangan (OJK), in early 2017 there are 116 brands of banks that operate and spread across Indonesia. It increases the difficulty of reaching new customers and becomes a challenge to retain current customers. Service quality, customer satisfaction and corporate image leads to opportunities to achieve new customer loyalty and retain current customers. Companies that have been successfully marked promising consumer growth and always generate loyal customers.

Today customers have the power of choosing, better at processing information and asking for the highest value for them. Levitt [1] stated that consumers are unpredictable, highly varied, ever-changing, shortsighted, stubborn and generally troublesome. The bank must understand the current situation and immediately leave a bad habit, that is ignoring the interests of its customers to be satisfied through the quality of its services. When this is ruled out, then the bank is preparing to accept the worst thing that could happen, that is abandoned by its customers. Customers who have been achieved are treated as well as possible in order to grow their loyalty to the bank. Therefore, the strategy to customers is adjusted to the business model and mission of the bank so that the bank can recognize its customers better. Based on this case, this study aims to determine the effect of service quality, customer satisfaction and corporate image of customer loyalty in Indonesia.

\section{Service Quality}

\section{Literature Review}

Specifically in the field of banking, service quality variable has become a major topic in the development of service marketing theory alongside discussion of customer satisfaction variables [2], [3]. Anderson and Olsen [4] conclude that service quality to customers can retain the right customers. Therefore it makes it a top priority to form customer equity and to retain profitable customers properly. Service quality is seen as a competitive advantage for the organization to differentiate itself from other competitors. It is very important to determine the long-term profit organization of the service organization. Good service will attract potential customers and retain existing customers.

Service quality has become the main tool to know the level of customer satisfaction. The results of several studies indicate that service quality has a positive effect on satisfaction [5], [6], [7], [8]. One of these studies found that service quality has a positive significant impact on customer satisfaction. Knowledge of 
products and fast service were found to be the factors that are positively associated with overall satisfaction. Research conducted in public sector banks and private sector banks [8].

Service quality becomes the determinant of customer loyalty [9]. According to Aydin and Zer, corporate image also become the major antecedent of customer loyalty. Zameer et al. [10] found the influence of service quality, customer satisfaction and corporate image on customer's perceived value that helps the service sector, especially banks, how they can increase the perceived value of customers through improved service quality, customer satisfaction and corporate image. So this research can draw the following hypothesis :

$\mathrm{H} 1$ : Service quality has a significant influence on customer satisfaction.

$\mathrm{H} 2$ : Service quality has a significant influence on corporate image.

H3 : Service quality has a significant influence on customer loyalty.

\section{Customer Satisfaction}

Oliver has stated that customer satisfaction and dissatisfaction regarding disconfirmation of consumer expectations. Satisfaction has been defined as the level of emotional reactions from service experience [11]. Thus, satisfaction is based on direct past experience. Kandampully and $\mathrm{Hu}$ [12] stated that corporate image is influenced both by service quality and customer satisfaction, which in turn influences customer loyalty. The results of their research have shown that the key customer loyalty seems to be the coaching of a good corporate image created by improving the quality of service and satisfying the customers. Loverlock [13] identified customer satisfaction as an important driving force for customer loyalty and demonstrated a marked positive correlation between the two. The results of research have shown that customer satisfaction has a direct influence on customer loyalty. Customer satisfaction has become the main variable that has determined customer loyalty [14], [15], [16]. This study creates the following hypotheses for further examination:

$\mathrm{H} 4$ : customer satisfaction has a significant influence on corporate image.

H5 : customer satisfaction has a significant influence on customer loyalty.

\section{Corporate Image}

Walters [17] stated that corporate image includes a consumer picture of organizational image, functional image and merchandize image. The results of the study from Hatch et al. [18] stated that corporate image encompasses the feelings of company employees and the perspectives of customers, shareholders, the media, the general public and external interested parties on the corporation. Two research results show that corporate image and service quality as a form of customer loyalty [19], [9]. Nguyen and Leblanc [20], [21] found that corporate image relates positively with customer loyalty. Their observations on the three sectors are education, retail and telecommunications. They stated that corporate image is related to the physical and behavioral attributes of the firm, such as business name, architecture, variety of products/services, and to the impression of quality communicated by each person interacting with the firm's clients. The following hypothesis is going to be tested for further analysis:

H6 : corporate image has a significant influence on customer loyalty.

\section{Customer Loyalty}

Customer loyalty remains one of the most important factors in determining market competitiveness. According to Griffin [22], the conceptualization of customer loyalty leads more to a form of behavior rather than a form of attitude. Griffin has argued that through the loyalty of front-line employees to the company will lead to a better quality of customer relationships. Frontline employees represent a representative of the company's products and services. This can lead to the achievement of customer loyalty through their performance. The performance of front-line employees will be delivered through service quality to customers. Customer loyalty considered as backbone for firms as it is way for sustaining and increasing sales. As well as it plays important role for increasing profits, as it is obvious from previous researches the cost of obtaining new customers is much higher than to serve current customers [23]. 


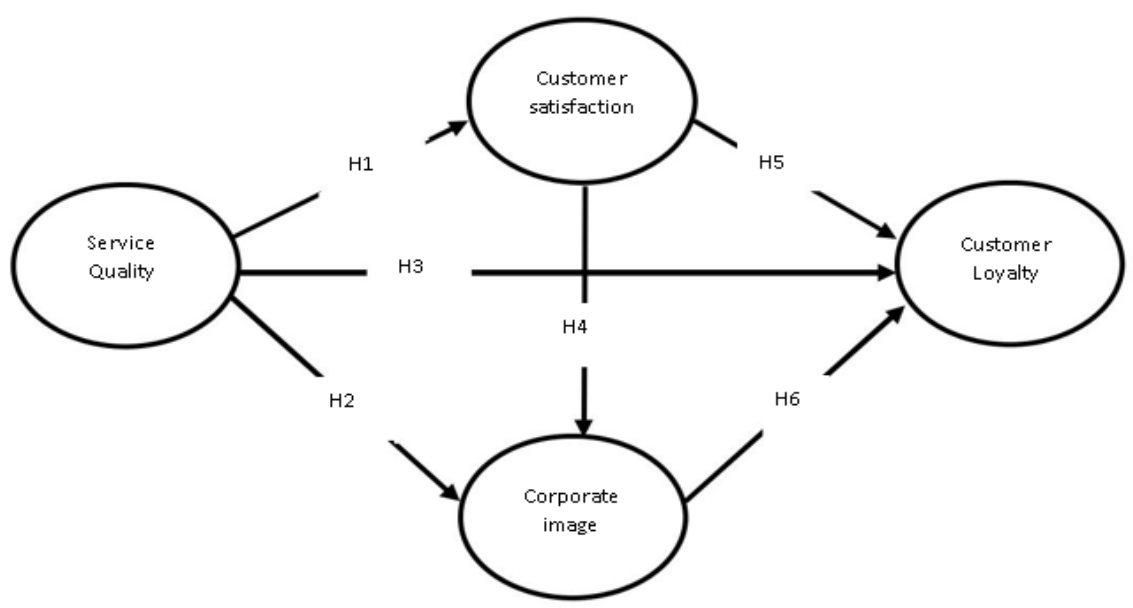

Figure 1: Conceptual Framework of The Proposed Study

\section{Conceptual Framework}

This framework is developed to show the relationship between service quality, corporate image and customers satisfaction towards customer loyalty taken from the existing literature and predefined hypotheses. The framework is shown in Figure 1as below.

\section{Methodology}

Data analysis technique used in this research is Structural Equation Model (SEM) which is set of statistical techniques that have the ability to test a complex relationship framework. Software used is AMOS. As for the data tabulation used SPSS 23 software. The data were collected from January - March 2017 using sampling technique with sampling area in five cities in East Java. The five cities are Surabaya, Malang, Sumenep, Jember and Tuban. According to Hair et al. [24], minimal data for SEM data analysis techniques as many as 100 samples. The population in this study are bank customers in East Java who have high involvement in the decision-making process. This study involved 250 respondents through data collection from questionnaires and interviews. The Respondents are individual customers of the five largest banks in Indonesia. The five banks are BRI, BCA, Mandiri, BNI, BTN. The number of respondents was taken each of 50 customers for each bank

Question items based on indicators of the research variables are service quality, customer satisfaction, corporate image and customer loyalty. The basic purpose of this survey is to find out how respondents think about service quality, customer satisfaction, corporate image and customer loyalty with each bank.

\section{Analysis Of Result}

Analysis of the research results begins by examining the scale of measurements in this study that will be used for regression analysis and establishing a structural model through the AMOS program as shown in Figure 3. In Figure 2 shows the results of Confirmatory factor analysis (CFA) to test empirically the measurement model. Use of validity and reliability test for the accuracy of research constructs. In addition, using the maximum likelihood (ML) method will be examined fitnya model.

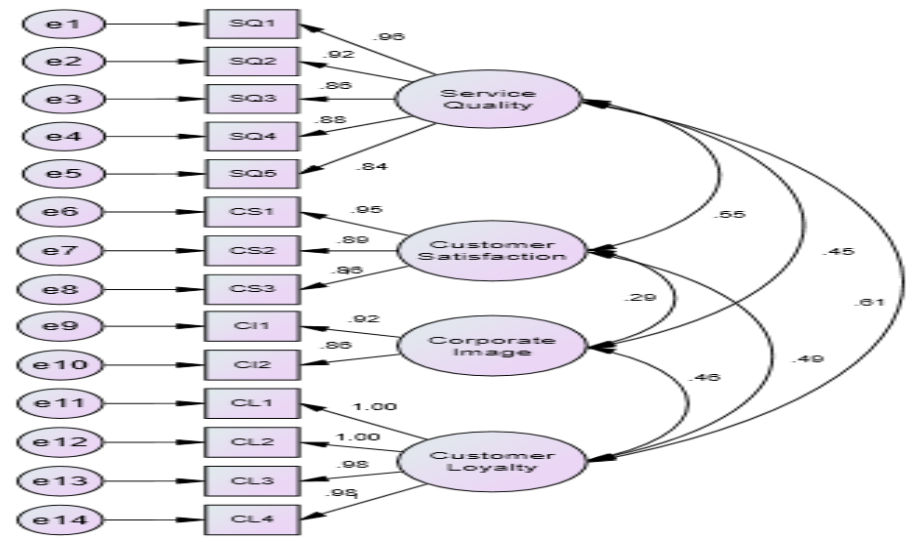

Figure 2: Confirmatory factor analysis - CFA 
Reliability test based on $\alpha$ Cronbach and composite reliability (CR) values using CFA. As in Table 1 indicates that all constructs are greater than 0.60 which means that the measurement scale for analysis is acceptable or reliable. The CR value is above the cut-off of 0.70 . It shows that the stages in this study are acceptable to reinforce the reliability of the construct as shown in Table 1. Test validity consists of three forms of content, convergent, and discriminate validities. Content validity is done during the review and pervious empiricall Researches literature. Convergent validity test was observed by observing factor loadings and average variance extracted (AVE) values. The factor loadings value must be higher than 0.70 and the recommended AVE value exceeds the value 0.50. Based on Table 1 it is fulfilled.

Table 1: Results for the Measurement Model

\begin{tabular}{|c|c|c|c|c|c|}
\hline Construct & Items & Factor loading & AVE & CR & Cronbach's $\alpha$ \\
\hline \multirow{5}{*}{ Service Quality } & SQ11 & 0.956 & \multirow{5}{*}{0.941} & \multirow{5}{*}{0.952} & \multirow{5}{*}{0.952} \\
\hline & SQ12 & 0.921 & & & \\
\hline & SQ13 & 0.864 & & & \\
\hline & SQ14 & 0.881 & & & \\
\hline & SQ15 & 0.843 & & & \\
\hline \multirow{2}{*}{ Corporate Image } & CI1 & 0.916 & \multirow{2}{*}{0.853} & \multirow{2}{*}{0.877} & \multirow{2}{*}{0.871} \\
\hline & CI2 & 0.857 & & & \\
\hline \multirow{3}{*}{ Customer Satisfaction } & CS1 & 0.952 & \multirow{3}{*}{0.916} & \multirow{3}{*}{0.932} & \multirow{3}{*}{0.931} \\
\hline & $\mathrm{CS} 2$ & 0.893 & & & \\
\hline & $\mathrm{CS} 3$ & 0.863 & & & \\
\hline \multirow{4}{*}{ Customer Loyalty } & CL1 & 0.997 & \multirow{4}{*}{0.995} & \multirow{4}{*}{0.997} & \multirow{4}{*}{0.996} \\
\hline & CL2 & 0.998 & & & \\
\hline & CL3 & 0.987 & & & \\
\hline & CL4 & 0.982 & & & \\
\hline
\end{tabular}

To test the discriminant validity, the root square of the AVE for each construct value must be more than the correlation value between the constructs. Table 2 shows the root value of AVE greater than the correlation between constructs.

Table 2: Correlations and Square Root of the AVE

\begin{tabular}{|c|c|c|c|c|}
\hline & Service Quality & Corporate Image & $\begin{array}{c}\text { Customer } \\
\text { Satisfaction }\end{array}$ & $\begin{array}{c}\text { Customer } \\
\text { Loyalty }\end{array}$ \\
\hline Service Quality & 0.893 & & & \\
\hline Corporate Image & 0.452 & 0.881 & & \\
\hline Customer Satisfaction & 0.548 & 0.287 & 0.921 & \\
\hline Customer Loyalty & 0.608 & 0.463 & 0.491 & 0.988 \\
\hline
\end{tabular}

Fit indices calculated for the measurement model indicated a good fit between the structural model and data [25], [26], [27]. Table 3 provides the value of the fit indices of the model.

Table 3: Measurement Model Fit Indices

\begin{tabular}{|c|c|c|}
\hline Fit indices & Recommended Value & $\begin{array}{c}\text { Value } \\
\text { Indices }\end{array}$ \\
\hline Chi-Square $\left(\mathrm{X}^{2} / d f\right)$ & $<3.00$ & 2.671 \\
\hline Goodness of Fit Index (GFI) & $>0.90$ & 0.908 \\
\hline Normed Fit Index (NFI) & $>0.90$ & 0.969 \\
\hline Comparative Fit Index (CFI) & $>0.90$ & 0.977 \\
\hline Incremental Index of Fit (IFI) & $>0.90$ & 0.977 \\
\hline Relative Fit Index (RFI) & $>0.90$ & 0.962 \\
\hline Tucker-Lewis Index (TLI) & $>0.90$ & 0.973 \\
\hline Root Mean Square Error of Approximation (RMSEA) & $<0.05$ & 0.75 \\
\hline
\end{tabular}

Regarding the hypothesis tests, as shown in Table 4, all the hypothesized relationships are supported in the estimated structural model.

Table 4: Result of the Structural Model

\begin{tabular}{|c|c|c|c|c|c|}
\hline \multicolumn{2}{|c|}{ Structural equations } & Coeff. $(\beta)$ & t-values & $\mathrm{P}$ & Result \\
\hline Service Quality & Customer Satisfaction & 0.26 & 4.178 & $* * *$ & Supported \\
\hline Service Quality & Corporate Image & 0.32 & 5.655 & $* * *$ & Supported \\
\hline Service Quality & Customer Loyalty & 0.24 & 4.042 & $* * *$ & Supported \\
\hline Customer Satisfaction & Corporate Image & 0.44 & 7.942 & $* * *$ & Supported \\
\hline
\end{tabular}


The Effect of Service Quality, Customer Satisfaction and Corporate Image...

\begin{tabular}{|c|l|l|l|l|l|}
\hline Customer Satisfaction & Customer Loyalty & 0.19 & 3.556 & $* * *$ & Supported \\
\hline Corporate Image & Customer Loyalty & 0.38 & 6.082 & $* * *$ & Supported \\
\hline
\end{tabular}

As shown in Fig. 3, service quality has significant positive effects on customer satisfaction ( $\beta=0.26$, tvalue $=4.178)$ and corporate image $(\beta=0.32$, tvalue $=5.655)$ and customer loyalty $(\beta=0.24$, t -value $=4.042)$. Hence, H1, H2 and H3 are supported. Furthermore, customer satisfaction also has significant positive effects on corporate image $(\beta=0.44$, $t$-value $=7.942)$ as well as customer loyalty $(\beta=0.19$, t-value $=3.556)$, indicating that $\mathrm{H} 4$ and $\mathrm{H} 5$ are supported. Finally, a significant positive effect of corporate image on customer loyalty $(\beta=0.38$, $\mathrm{t}$-value $=6.082)$ is also found, and thus H6 is supported.

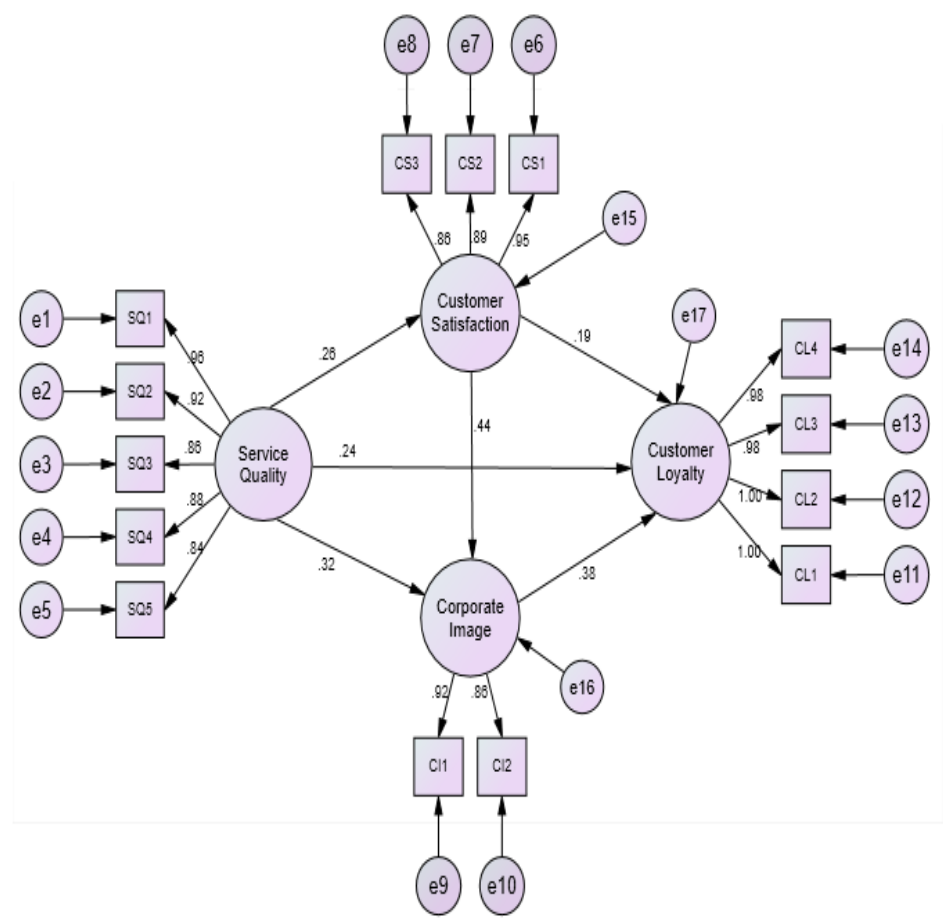

Figure. 3: Structural model

\section{Conclusions And Implications}

The research results indicate that service quality has significant positive effects on customer satisfaction, corporate image, and customer loyalty. Also, customer satisfcation has significant positive effects on corporate image. Finally, both of customer satisfaction and corporate image are found to have a significant positive effect on customer loyalty. The model indicates that corporate image has the bigger effect on customer loyalty when compared with both service quality and customer satisfaction. Also service quality can enhance and create both of customer satisfcation and corporate image. The results indicate that service quality makes a significant contribution to the achievement of customer satisfaction and corporate image. Thus service quality and customer satisfaction become the main thing in the formation of a good corporate image. Service quality, customer satisfaction, and corporate image contribute to the attachment of customer loyalty. Aaker [28] stated that a brand that does not have a loyal consumer base will be vulnerable to competitors. The advantage of having loyal customers is the cost of maintaining them is cheaper than looking for new customers. In addition, for competitors to seize loyal customers, costly. All companies must estimate the value of their customers' existence. A bank with a branch system that maintains 5\% of its customers to remain loyal will generate $85 \%$ profit for the company [29] - The banking system in Indonesia is more appropriate with this system because of its favorable geographical conditions. This system means that existing banks must develop themselves by opening many branches with emphasis on branch operational efficiency and quality of branch services.

The results of this study suggest to the bank to seek services and products that suit and able to satisfy customers not to lose them. The bank should provide special treatment to the loyal customers, but without distinguishing the main services received by each customer. The loyal customer data owned by the bank will help to understand the transaction pattern of the customer. From the previous description, there are two reasons why this is done. Firstly, because the cost of acquiring new customers is more expensive than maintaining loyal 
customers. Second, the practical function of loyal customers are promoters for their consumption experience or often called word of mouth and positive reference is the beginning of direct communication to the public. Banks that focus on their customers will make the satisfaction of their customers as their target and marketing tool.

Further studies should research the impact of service quality, customer satisfaction and corporate image on customer loyalty enhancement in different populations and in different contexts. In addition, further study is needed on relationship marketing and customer relationship management to formulate a relationship marketing strategy as a competitive advantage to retain their current customers through long-term and stable relationships and seek feedback to improve customer satisfaction and loyalty.

\section{References}

[1]. Levitt's, Theodore. 1960. "Marketing Myopia”, Harvard Business Review, Juli-Agustus. pp. 45-56

[2]. Avkiran, N. K. 1994. "Developing an Instrument to Measure Customerservice Quality in Branch Banking”, International Journal of Bank Marketing, Vol.12(6), pp.10-18

[3]. Jamal, A., \& Naser, K. 2002. "Customer Satisfaction and Retail Banking: An Assessment of Some of the Key Antecedents of Customer Satisfaction in Retail Banking”, International Journal of Bank Marketing, Vol. 20(4), 146-160.

[4]. Anderson, T.W.\& Olsen. L.L. 2008. "The Impact of Customers' Perception of Varying Degrees of Customer Service on Commitment and Perceived Relative Attractiveness", Managing Service Quality, Vol. 18( 4), pp.309-328

[5]. Cronin, J.J \& S.A. Taylor 1992 "Measuring Service Quality : A Re-examination and Extension", Journal of Marketing, Vol 56 No.3, July, pp.56-68

[6]. Aldlaigan, A. H., \& Buttle, F. A. 2002. "SYSTRA-SQ: A New Measure of Bank Service Quality", International Journal of Service Industry Management, Vol. 13(4), pp.362-381

[7]. Bei, L. T., \& Chiao, Y. C. 2006. "The Determinants of Customer Loyalty: An Analysis of Intangible Factors in Three Service Industries", International Journal of Commerce and Management, Vol.16(3/4), 162-177.

[8]. Paul, Justin., Arun Mittal, Garima Srivastav. 2016. "Impact of Service Quality on Customer Satisfaction in Private and Public Sector Banks", International Journal of Bank Marketing, Vol. 34 Issue: 5, pp.606-622,

[9]. Aydin, S. \& Zer, O. G. 2005. "The Analysis of Antecedents of Customer Loyalty in the Turkish Mobile Telecommunication Market”, European Journal of Marketing, Vol.39 (7/8), pp.910-925

[10]. Zameer, Hashim., Anam Tara, Uzma Kausar, Aisha Mohsin, 2015 "Impact of Service Quality, Corporate Image and Customer Satisfaction Towards Customers' Perceived Value in the Banking Sector in Pakistan", International Journal of Bank Marketing, Vol. 33 Issue: 4, pp.442-456

[11]. Oliver, R. L. 1980. "A Cognitive Model of the Antecedents and Consequences of Satisfaction Decisions", Journal of Marketing Research, Vol. 17 (November), pp.460-9.

[12]. Kandampully, Jay \& Hsin-Hui Hu. 2007. "Do Hoteliers Need to Manage Image to Retain Loyal Customers?", International Journal of Contemporary Hospitality Management, Vol. 19 Issue: 6, pp.435-443

[13]. Lovelock, Christopher H. 1996. Service Marketing, 3rd edition, London: Prentice-Hall

[14]. Anderson, Eugene W., Claes. Fornell, Donald R. Lehman. 1994. "Customer Satisfaction, Market Share, and Profitability : Finding from Sweden", Journal of Marketing, Vol.58. July, pp. 53-65.

[15]. Oliver, Richard L. 1999, "Whence Consumer Loyalty?” Journal of Marketing, Vol. 63 (Special Issue), pp.33-44.

[16]. Davis, B.R. \& Mentzer, J.T. 2006. "Logistics service driven loyalty: An exploratory study", Journal of Business Logistics, Vol. 27(2): pp.53-73.

[17]. Walters, C.G. 1978. Consumer Behavior: An Integrated Framework. New York: Richard D. Irwin Inc.

[18]. Hatch, M.J., Schultz, M., \& Williamson, J. 2003. "Bringing the Corporation into Corporate Branding", European Journal of Marketing, Vol. 37(7/8): 1041-64

[19]. Johnson, M.D., Gustafsson, A. \& Andreassen, T.W. 2001. "The Evolution and Future of National Customer Satisfaction Index Models", Journal of Economic Psychology, Vol. 22(2), 217-45.

[20]. Nguyen, N \& Leblanc, G. 1998. "The Mediating Role of Corporate Image on Consumers Retention Decisions: an Investigation in Financial Services", International Journal of Bank Marketing, Vol. 16 (2), 52-65.

[21]. Nguyen, N. \& Leblanc, G. 2001. "Corporate Image and Corporate Reputation in Customers' Retention Decisions in Services", Journal of Retailing and Consumer Services, Vol.8, pp.227-36.

[22]. Griffin, Jill. 2002. Customer Loyalty : How to earn it, How to Keep it. San Francisco: Jossey-Bass

[23]. Reichheld, Frederick. F., \& Earl. Sasser. Jr. 1990. "Zero Defections: Quality Comes to Services", Harvard Business Review, September-October

[24]. Hair, J.F. JR.,Anderson, R.E, Tatham, R.L. \& Black, W.C. 1998. Multivariate Data Analysis. $5^{\text {th }}$ edition. New York : Prentice Hall

[25]. Kline, Rex. B. 2005. Principles and Practice of Structural Equation Modeling, $2^{\text {nd }}$ edition. New York : The Guilford Press

[26]. Bagozzi, Richarch P. \& Youjae Yi. 1988. "On the evaluation of structural equation models", Journal of the Academy of Marketing Science. Vol. 16, pp.74-94.

[27]. Jöreskog, KG \& Sörbom D. 1993. LISREL 8: Structural equation modeling with the SIMPLIS common language. New Jersey : Lawrence Erlbaum associates

[28]. Aaker, David. A. 1996. Building Strong Brand. New York : Simon \& Schuster Inc.

[29]. Reichheld, Frederick. F. 1993. "Loyalty-Based Management”, Harvard Business Review, March-April

Didit Darmawan The Effect of Service Quality, Customer Satisfaction and Corporate Image on Customer Loyalty in the banking sector in Indonesia. IOSR Journal of Business and Management (IOSR-JBM), vol. 19, no. 11, 2017, pp. 46-51. 